\title{
Mass balance-based plant-wide wastewater treatment plant models - Part 1: Biodegradability of wastewater organics under anaerobic conditions
}

MC Wentzel, GA Ekama* and SW Sötemann

Water Research Group, Department of Civil Engineering, University of Cape Town, Rondebosch, 7701, Cape, South Africa

\section{Abstract}

From an experimental and theoretical investigation of the continuity of wastewater organic chemical oxygen demand (COD) and nitrogen $(\mathrm{N})$ compounds along the link connecting the primary settling tank (PST) and anaerobic digester (AD), it was found that the primary sludge (PS) characteristics, viz. the biodegradable and unbiodegradable soluble and particulate COD and $\mathrm{N}$ component concentrations, need to be calculated from mass balances around the PST so that the organic and N concentrations conform to continuity principles, and the influent unbiodegradable particulate organics determined from response of the activated sludge (AS) system are also unbiodegradable under AD conditions.

Keywords: wastewater treatment, primary settling tank, anaerobic digestion, biodegradability, model validation.

\section{List of abbreviations}

AD anaerobic digestion

AerD aerobic digestion

Alk alkalinity with respect to the $\mathrm{H}_{2} \mathrm{CO}_{3} *$ reference species

ADWF average dry weather flow

AS activated sludge

ASM1,2,3 Activated Sludge Models No. 1, 2 or 3

BEPR biological excess phosphorus removal

BNR biological nutrient removal

C carbon

${ }^{\circ} \mathrm{C} \quad$ degrees Centigrade

$\mathrm{Ca} \quad$ calcium

COD chemical oxygen demand

d day

Eq equation

FSA free and saline ammonia

$\mathrm{H}$ hydrogen

ISS inert suspended solids

K potassium

$\ell \quad$ litres

$\mathrm{Mg}$ magnesium

$\mathrm{N} \quad$ nitrogen

ND nitrifying - denitrifying

NDBEPR nitrifying - denitrifying biological excess phosphorus removal

O oxygen

$\mathrm{OHO}$ ordinary heterotrophic organism

OP ortho-phosphorus
ADM1 Anaerobic Digestion Model No. 1

\begin{tabular}{|c|c|}
\hline OrgN & organic nitrogen \\
\hline OTR & oxygen transfer rate \\
\hline OUR & $\begin{array}{l}\text { oxygen utilisation rate, subscripts } \mathrm{c}, \mathrm{n} \text { and } \mathrm{t} \text { denote } \\
\text { carbonaceous, nitrification and total }\end{array}$ \\
\hline $\mathrm{P}$ & phosphorus \\
\hline PAO & phosphorus accumulating organism \\
\hline $\mathrm{pH}$ & negative $\log$ of the hydrogen ion activity \\
\hline PS & primary sludge \\
\hline PST & primary settling tank \\
\hline Q & flow \\
\hline $\mathrm{R}$ & $\begin{array}{l}\text { hydraulic retention time or sludge age for anaerobic } \\
\text { digester }\end{array}$ \\
\hline RBCOD & readily biodegradable COD \\
\hline SBCOD & slowly biodegradable COD \\
\hline SOUR & $\begin{array}{l}\text { specific oxygen utilisation rate }(\mathrm{mgO} /(\mathrm{gVSS} . \mathrm{d}) \text {. } \\
\text { Subscripts } \mathrm{c}, \mathrm{n} \text { and } \mathrm{t} \text { denote carbonaceous, nitrifica- } \\
\text { tion and total. }\end{array}$ \\
\hline SS & settleable solids \\
\hline TKN & total Kjeldahl nitrogen \\
\hline TP & total phosphorus \\
\hline TSS & total suspended solids \\
\hline $\mathrm{V}$ & volume \\
\hline VFA & volatile fatty acids \\
\hline VSS & volatile suspended solids \\
\hline VS & volatile solids \\
\hline WAS & waste activated sludge \\
\hline WW & wastewater \\
\hline WWTP & wastewater treatment plant \\
\hline
\end{tabular}

\section{List of symbols}

$b_{H}, b_{H} \quad$ OHO endogenous respiration and death rates (/d). Additional subscripts $\mathrm{T}$ and 20 denote rates at $\mathrm{T}$ and $20^{\circ} \mathrm{C}$

* To whom all correspondence should be addressed.

邑 +2721 650 2588; fax: +27 21689 7471;

$f_{a v} f_{a t} \quad$ OHO fraction of AS with respect to VSS and TSS. Additional subscripts i or e denote aerobic digester influent or effluent. 


\begin{tabular}{|c|c|}
\hline & \\
\hline & \\
\hline${ }_{E H} f_{E H}^{\prime}$ & $\begin{array}{l}\text { unbiodegradable fraction of OHOs in endogenous } \\
\text { respiration and death regeneration models }\end{array}$ \\
\hline$f_{i}, f_{i i}, f_{i e}$ & $\begin{array}{l}\text { VSS/TSS ratio of AS. Subscripts i and e denote } \\
\text { influent and effluent sludge. Subscript PS refers to } \\
\text { primary sludge. }\end{array}$ \\
\hline & Inorganic content of OHOs (mgISS/mgOHOVSS) \\
\hline & Nitrogen fraction of AS and PS (mgN/mgVSS) \\
\hline & Fraction of influent TKN that is FSA \\
\hline & $\begin{array}{l}\text { Fraction of influent TKN that is unbiodegradable } \\
\text { soluble OrgN }\end{array}$ \\
\hline & Fraction of COD removed by primary sedimentation \\
\hline & \\
\hline & denotes primary sludge \\
\hline & Fraction of unbiodegradable COD in AS and PS \\
\hline & $\begin{array}{l}\text { raction with respect to the } \\
\text { D }\end{array}$ \\
\hline , $f_{\text {S'us }}$ & $\begin{array}{l}\text { soluble unbiodegradable COD } \\
\text { ewater. }\end{array}$ \\
\hline & and $\mathrm{S}$ denote raw and settled \\
\hline$f_{v s r} f_{t s r}$ & VSS and TSS removed in aerobic \\
\hline & of PAOs (mgP/mgPAOVSS) \\
\hline$f_{Z B, N} f_{Z B, P}$ & s ( $\mathrm{mgN}$ or mgP per \\
\hline$N_{a i}$ & monia $(\mathrm{FSA})$ concentration $(\mathrm{mgN} / \ell)$ \\
\hline$N_{o b p i}, N_{o b s i}$ & $\begin{array}{l}\text { iculate and soluble } \\
\text { l) }\end{array}$ \\
\hline$N_{\text {oupi }}, N_{\text {ousi }}$ & articulate and soluble \\
\hline$O$ & $\begin{array}{l}\mathrm{O} /(\ell \cdot h)] . \text { Subscripts } \mathrm{c}, \mathrm{n} \\
\text { nitrification and total }\end{array}$ \\
\hline & Partial pressure of $\mathrm{CO}_{2}$ \\
\hline$Q_{i}$ & \\
\hline$R_{h}$ & Hydraulic retention time $(\mathrm{d})$ \\
\hline$R_{s}$ & Sludge age (d) \\
\hline$R^{2}$ & Correlation coe \\
\hline$S_{b p}$ & able particulate organics concentration \\
\hline$S_{b p i}, S_{b s i}$ & $\begin{array}{l}\text { Influent biodegradable particulate and soluble COD } \\
\text { concentrations }(\mathrm{mgCOD} / \ell)\end{array}$ \\
\hline$S_{t i}, S_{t e}$ & $\begin{array}{l}\text { Total influent and effluent COD concentration } \\
(\mathrm{mgCOD} / \ell)\end{array}$ \\
\hline$S_{u p i}, S_{u s i}$ & $\begin{array}{l}\text { Influent unbiodegradable particulate and soluble } \\
\text { COD concentrations }(\mathrm{mgCOD} / \ell)\end{array}$ \\
\hline$V_{d}$ & Volume of digester \\
\hline & OHO biomass concentration (mgVSS/l) \\
\hline & $\mathrm{OHO}$ endogenous residue concentration $(\mathrm{mgVSS} / \ell)$ \\
\hline$X_{p}^{n+}$ & $\begin{array}{l}\text { ics concentration in reactor } \\
\text { subscript } \mathrm{i} \text { denotes influent. }\end{array}$ \\
\hline$X_{I o}, X_{I o i}$ & $\begin{array}{l}\text { ISS (fixed and biomass) concentration in reactor } \\
\text { (mgISS/l). Additional subscript i denotes influent. }\end{array}$ \\
\hline$X_{v}, X_{v i}, X_{v e}$ & $\begin{array}{l}\text { VSS concentration }(\mathrm{mgVSS} / \ell) \text {. Additional subscript } \\
i \text { and e denote influent and effluent. }\end{array}$ \\
\hline${ }_{i}, X_{t e}$ & $\begin{array}{l}\text { TSS concentration (mgTSS/l). Additional subscript } \\
i \text { and e denote influent and effluent. }\end{array}$ \\
\hline & OHO yield coefficient (mgVSS/mgCOD) \\
\hline & $\begin{array}{l}\text { substitution variables in VSS and TSS based steady } \\
\text { state AerD model }\end{array}$ \\
\hline & mgO required per mgFSA-N nitrified to nitrate \\
\hline
\end{tabular}

\section{Introduction}

To aid the design and operation of, and research into activated sludge (AS) biological wastewater treatment systems, a variety of mathematical models have been developed. For these models the primary focus has been on the individual unit operation of the AS system, since this is the unit operation that produces the effluent that must comply with legislated effluent criteria. As a consequence the AS system has been well researched and relatively reliable simple steady state design (e.g. WRC, 1984; Wentzel et al., 1990; Maurer and Gujer, 1994) and complex dynamic simulation models (e.g. Dold et al., 1980, 1991; Wentzel et al., 1992; Henze et al., 1987, 1995) have been developed for the system, including biological $\mathrm{N}$ and/or P removal. With the publication of the ADM1 (Batstone et al., 2002), there is a growing drive to develop plant-wide WWTP simulation models.

The WWTP comprises a sequence of individual unit operations (e.g. primary settling, AS, secondary settling, anaerobic digestion, AD). These individual unit operations are interconnected through a network of flows: The outputs from upstream unit operations become inputs to downstream unit operations; further, it is common practice at WWTPs to recycle various liquors (e.g. sludge thickening and AD supernatants) from downstream unit operations to upstream ones. This interconnection of individual unit operations means that design and operation optimisation of one unit operation can have unexpected and sometimes unforeseen consequences on the performance (and economics) of both upstream and downstream unit operations, and hence on the WWTP performance as a whole. For example, the recycling of nutrient-rich liquors from sludge treatment unit operations to the AS system has a significant impact on the WWTP effluent quality (e.g. Pitman et al., 1991; Wild and Siegrist, 1999), contributing up to $25 \%$ of the total N load to the AS system (Janus and Van der Roest, 1997).

\section{Advantages of WWTP material mass balances models}

To assess and quantify the interdependencies of the various unit operations making up the WWTP, models that track materials of importance through the WWTP on a mass balance basis are required. Materials mass balance based models of the entire WWTP would be a valuable tool to aid optimisation of WWTP design and performance. Potential advantages of such models are that they allow for design and operation:

- Tracking compounds through the WWTP to ensure continuity - currently little more than TSS is used mostly manually to assess loads and capacities on different unit operations in a WWTP sequence; TSS as measured is not mass conservative and provides no assessment of mass balances and continuity for the sequence of unit operations of the WWTP.

- Identifying characteristics of streams from one unit operation (e.g. primary settling) to a downstream one (e.g. aerobic/anaerobic digestion); this will assist in design and performance assessment and optimisation of the various unit operations in the WWTP.

- Assessing the impact of recycling sludge thickening and dewatering liquors from downstream operations on upstream operations.

- Identifying bottlenecks and overloaded unit operations which limit the capacity of the WWTP. 
- Optimising unit operations for maximum throughput and minimum impact on effluent quality and upstream units.

- Identifying from the influent wastewater characteristics, and the type, design and operation of the specific unit operations making up the WWTP, the extent to which mineral precipitation problems will arise in the sludge treatment operations.

- Assessing the impact of interventions, such as including additional unit operations in the WWTP sequence like phosphorus precipitation or nitrification of recycling liquors.

- Identifying WWTP operational and analytical data that do not conform to mass balance and continuity principles - from the writers' experience something as basic as flow measurement can have significant errors (up to 50\%), leading to poor load distribution on parallel units and inefficient and uneconomical operation of the WWTP.

\section{Requirements for mass balance WWTP models}

A requirement of plant-wide WWTP mass balances models is that all materials of importance in all of the individual unit operations are included, so that materials are common at the interconnections (links) between unit operations (Wild and Siegrist, 1999). This aspect is receiving research attention in plant-wide WWTP simulation models development which link the ASM1 (Henze at el., 1987) and ADM1 (Copp et al., 2003, 2004). This requires modelling parameters in an individual unit operation that may not be of significance to that unit operation, but may be crucial to a unit operation that receives the output. For example, in AS models $\mathrm{C}$ is not usually included as a compound, but $\mathrm{C}$ is important in the $\mathrm{AD}$ of sewage sludges because it determines gas production and composition, and influences the $\mathrm{pH}$ established through the weak acid/base chemistry. Towards this end, Sötemann et al. (2005a) developed a two phase (aqueous-gas) integrated chemical, physical and biological process simulation model based on ASM1 including organic and inorganic carbon, and Huete at al. (2005) have proposed a wastewater characterisation scheme based on $\mathrm{C}, \mathrm{H}, \mathrm{O}, \mathrm{N}$ and $\mathrm{P}$ elemental composition of the important groups of influent organics. The overall objective is to develop materials mass balance models for the entire WWTP including all materials of importance such as COD (electron), C, N, P, alkalinity (proton), Ca and Mg. Also, because of its importance in accepted design procedures for the various unit operations (e.g. secondary settling tanks), the inorganic suspended solids (ISS) concentration needs to be included to be able to calculate the TSS concentration.

\section{Steady state vs. dynamic simulation models}

In most WWTPs, unit operations in which transformations of the materials take place that need to be modelled are primary sedimentation, biological wastewater treatment in AS systems, including or excluding biological $\mathrm{N}$ and $\mathrm{P}$ removal, sludge thickening and aerobic and anaerobic stabilisation of primary and secondary sludges, for both steady state and dynamic simulation conditions. Steady state biological process models are simplifications of the complex simulation ones. They generally are based on stoichiometry and the slowest process kinetic rate that governs the overall behaviour of the system and relate these to system design and operating parameters. Therefore, steady state models are useful to:

- Estimate reasonably simply and quickly the principal system design and operating parameters, which are required as input to simulation models, such as sludge age, reactor volume, recycle ratios and oxygen requirement or gas production from system performance criteria specified for the design, such as effluent quality

- Investigate the sensitivity of the system performance to the design and operation parameters

- Estimate product stream concentrations for design of down(or up-) stream unit operations of the WWTP

- Very importantly, provide a basis for cross-checking simulation model output results.

Once the overall WWTP scheme is established and the main system defining parameters of the individual unit operations estimated, complex simulation models can be applied to the individual unit operations to refine their design and evaluate their performance under cyclic flow and load conditions. Accordingly, both steady state and dynamic simulation WWTP models need to be developed.

In this series of four papers, the focus is on using steady state models and experimental data to answer some important questions that arise when linking WWTP unit operations, such as:

- Are unbiodegradable organics, as defined by the "aerobic" AS system, also unbiodegradable under AD conditions?

- Is the influent ISS conserved through the WWTP?

For this, the four main links between common unit operations of WWTPs are considered using mass balance-based steady state models for the AS system and aerobic (AerD) and anaerobic (AD) digestion, viz:

- The PST - AD link (this paper)

- The AS system - AerD link (Part 2, Ekama et al., 2006a)

- The AS system - AD link (Part 3, Ekama et al., 2006b)

- The PST - AerD link (Part 4, Sötemann et al., 2006).

Where feasible steady state model outputs will be compared with the more complex dynamic simulation models. In this development only $\mathrm{N}$ removal AS systems will be considered and where required, steady state models will be developed or extended to ensure common materials at the links between the unit operations, and thus allow integrated design of the different unit operations making up the WWTP. Only unit operations in which the biological processes dominate are considered, viz. N removal AS, AerD and AD. Unit operations in which physical processes dominate, such as primary sedimentation, sludge thickening before and dewatering after sludge digestion are regarded as solid/liquid separators and solids concentrators only. Several complex issues which require further experimental research remain around aerobic and anaerobic digestion of WAS which include PAOs and so BEPR AS systems are not considered in this series of four papers.

\section{The primary settling tank (PST) - anaerobic digester (AD) link}

\section{Mass balance steady state AD model}

The steady state anaerobic digestion model of Sötemann et al. (2005b) provides the framework for considering this link. This model allows determination of the unbiodegradable particulate COD fraction of PS $\left(f_{P^{\prime} \text { up }}\right)$ to correctly predict the anaerobic digester COD (VSS) removal, gas flow and composition, ammonia released, alkalinity generated and $\mathrm{pH}$. For this they developed a COD, C, H, O and $\mathrm{N}$ mass balances steady state model comprising three parts: 
- A kinetic part for the hydrolysis of biodegradable particulate organics from which the \% COD removal and methane production are determined for a given retention time

- A stoichiometry part from which the gas composition (or partial pressure of carbon dioxide, $\mathrm{p}_{\mathrm{CO} 2}$ ), free and ammonia (FSA) released and alkalinity (Alk) generated are calculated from the $\%$ COD removal

- A carbonate system weak acid/base chemistry part from which the digester $\mathrm{pH}$ is calculated from the partial pressure of $\mathrm{CO}_{2}$ and alkalinity generated.

From the stoichiometry and weak acid/base chemistry parts of the model, for a given COD removal, the digester gas composition, ammonia released, alkalinity generated and digester $\mathrm{pH}$ are completely defined by the influent sludge composition, i.e. $\mathrm{X}, \mathrm{Y}, \mathrm{Z}$ and $\mathrm{A}$ in $\mathrm{C}_{\mathrm{X}} \mathrm{H}_{\mathrm{Y}} \mathrm{O}_{\mathrm{Z}} \mathrm{N}_{\mathrm{A}}$ of the hydrolysable organics, volatile fatty acid (VFA) concentration, and $\mathrm{pH}$. This approach is the same as is done in ADM1 (Batstone et al., 2002) in which the measured influent COD, C, H, O and $\mathrm{N}$ concentrations are transformed to concentrations of influent carbohydrates, lipids and proteins based on COD, $\mathrm{C}, \mathrm{H}, \mathrm{O}$ and $\mathrm{N}$ mass balances. The only difference in the steady state model is that $\mathrm{C}_{\mathrm{X}} \mathrm{H}_{\mathrm{Y}} \mathrm{O}_{\mathrm{Z}} \mathrm{N}_{\mathrm{A}}$ is the generic organic compound representing the mixture of influent carbohydrate, lipids and proteins with the measured $\mathrm{COD}, \mathrm{C}, \mathrm{H}, \mathrm{O}$ and $\mathrm{N}$ concentrations. The steady state model does not need to consider the organic intermediates because these are assumed to be completely utilised.

Once Sötemann et al. (2005b) calibrated the kinetic part of the model against experimental data of Izzett et al. (1992) and O'Rourke (1968) for two sewage sludge types, taking into account experimental COD mass balance error, the predicted COD removal and methane production compared well with the measured data. For the different sewage sludge types, viz. a primary and humus sludge mixture from a trickling filter plant (Izzett et al., 1992) and a "pure" PS (O'Rourke, 1968), different hydrolysis kinetic rate constants were obtained indicating that the "pure" PS hydrolysed faster and had a lower unbiodegradable particulate COD fraction $\left(f_{\text {PS'up }}\right.$

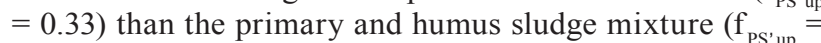
0.36). With the \%COD removal known from the hydrolysis part of the model, and again taking account of experimental $\mathrm{C}$ and $\mathrm{N}$ mass balance error, the stoichiometry and weak acid/base chemistry parts of the model predicted the gas composition, effluent free and saline ammonia (FSA) concentrations and alkalinity generated well for a primary and humus sludge composition of $\mathrm{C}_{3.5} \mathrm{H}_{7} \mathrm{O}_{2} \mathrm{~N}_{0.196}$. From elemental analysis of PS CHON composition from two Cape Town WWTPs, this model-estimated composition was within $96 \%$, $100 \%, 95 \%$ and $99 \%$ of the average measured composition of $\mathrm{C}_{3.65} \mathrm{H}_{7} \mathrm{O}_{1.97} \mathrm{~N}_{0.190^{\circ}}$. This validated the mass balance-based steady state AD model.

\section{Mass balances over the PST}

The unbiodegradable particulate COD fraction of PS $\left(\mathrm{f}_{\mathrm{PS}^{\prime} \text { up }}\right)$ determined from the validated AD model above is very close to that estimated from a mass balance around the primary settling tank (PST). From a COD mass balance of unbiodegradable and biodegradable particulate organics $\left(\mathrm{S}_{\mathrm{upi}}, \mathrm{S}_{\mathrm{bpi}}\right)$ around the PST, the $\mathrm{f}_{\mathrm{PS}^{\prime} \text { up }}$ is related to the raw and settled wastewater unbiodegradable COD fractions ( $\mathrm{f}_{\mathrm{S}^{\prime} \text { up }}$ ) and the fraction of COD removed in the PST $\left(\mathrm{f}_{\mathrm{PSR}}\right)$ as follows:

$$
f_{P S^{\prime} u p}=f_{S^{\prime} u p S}+\frac{1}{f_{P S R}}\left(f_{S^{\prime} u p R}-f_{S^{\prime} u p S}\right)
$$

where:

$$
\begin{aligned}
f_{P S^{\prime} \text { up }}= & \text { unbiodegradable particulate COD fraction of PS } \\
f_{S^{\prime} \text { up } S}= & \text { settled wastewater unbiodegradable particulate } \\
& \text { COD fraction } \\
f_{S^{\prime} \text { up } R}= & \text { raw wastewater unbiodegradable particulate } \\
& \text { COD fraction } \\
f_{P S R}= & \text { fraction of COD removed in the primary settling } \\
& \text { tank (PST) }
\end{aligned}
$$

Equation (1) has been simplified and is not strictly in conformity with a water flow balance over the PST, because it assumes that the raw and settled wastewater flows entering and exiting the PST are equal. In practice, this is not true, but due to the low PST underflow, typically between 0.5 and $1 \%$ of average dry weather flow (ADWF), the error on $\mathrm{f}_{\mathrm{PS} \text { up }}$ is very small. However, the error is large enough to cause an $\sim 1 \%$ underestimation of the COD mass balance around the whole WWTP. Mass balances are used wherever possible to verify the mathematical equations in models and errors $>1 \%$ are signals of possible errors in logic and formulae.

Similarly, by considering the differences in the organic $\mathrm{N}$ (and C, though not measured in this investigation) between raw and settled wastewater, the N (and C) content of the PS (settleable organics) can be determined.

\section{Unbiodegradable COD fraction of primary sludge $\left(\mathbf{f}_{\mathrm{PS} \text { 'up }}\right)$}

A graphical representation of Eq. 1 is given in Fig. 1. For typical South African raw and settled municipal wastewaters, $\mathrm{f}_{\mathrm{S}^{\prime} \text { up }}$ fractions are around 0.15 and 0.04 respectively (WRC, 1984). For these $\mathrm{f}_{\mathrm{S}^{\prime} \text { up }}$ fractions and $35 \%$ COD removal in the PST $\left(\mathrm{f}_{\text {PSR }}\right.$ $=0.35)$, the $\mathrm{f}_{\text {PS' up }^{\prime}}$ is 0.36 . This value is very close to the $\mathrm{f}_{\mathrm{PS}^{\prime} \text { up }}$ determined for the "pure" primary sludge of O'Rourke (1968) (0.33) and the primary/humus sludge mixture of Izzett et al. (1992) (0.36) by Sötemann et al. (2005b) with the steady state AD model, and for 'pure' PS (0.34) by Ristow et al. (2005) using a similar procedure. Also, literature on full-scale AD of primary sludge (PS) give maximum volatile solids (VS) removals at long retention times at around 0.60 (Eckenfelder, 1980), suggesting an unbiodegradable fraction of around 0.35. This demonstrates theoretically and experimentally that it is possible to determine the unbiodegradable particulate COD fraction of PS from a mass balance around the PST and the characteristics selected for the raw and settled wastewater entering and exiting it. In fact, it is necessary to do this to obtain consistent values for the unbiodegradable particulate COD fraction of raw and settled wastewater and the PS produced. It follows from the close correlation between the experimentally determined $\mathrm{f}_{\mathrm{PS}^{\prime} \text { up }}$ of PS in AD systems and that calculated from mass balance around the PST based on raw and settled wastewater unbiodegradable COD fractions determined in AS systems, that the influent organics that are unbiodegradable in the AS system treating raw wastewater are also unbiodegradable in the AD treating PS. From a modelling perspective, it can therefore be accepted that influent unbiodegradable particulate organics are unbiodegradable under both aerobic and anaerobic conditions.

\section{Characterising primary sludge organics}

The steady state AD model provides a structure for PS characterisation into biodegradable and unbiodegrada- 


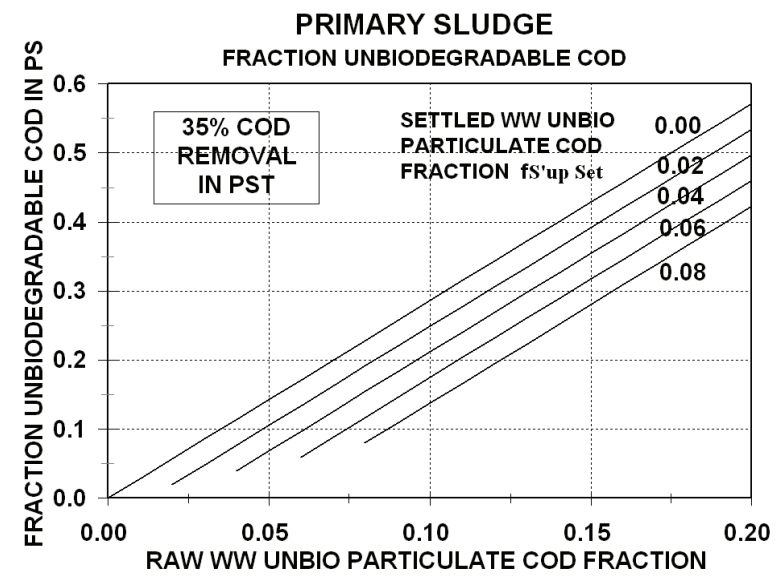

Figure 1

Fraction of unbiodegradable $C O D$ in primary sludge vs. raw wastewater unbiodegradable particulate $C O D$ fraction for different settled wastewater unbiodegradable particulate COD fraction

ble particulate COD fractions as well as for determining the $\mathrm{N}$ (and $\mathrm{C}$ ) content of these fractions. From the initial development of $\mathrm{N}$ removal AS models, the COD/VSS and N/VSS, and so also the N/COD ratios, of the influent unbiodegradable particulate organics have been accepted to be the same as those of the other two AS (VSS) constituents (OHO biomass and endogenous residue), i.e. $\mathrm{f}_{\mathrm{cv}}=1.48 \mathrm{mgCOD} / \mathrm{mgVSS}$ and $\mathrm{f}_{\mathrm{n}}=0.10 \mathrm{mgN} / \mathrm{mgVSS}$ (WRC, 1984 ) or equivalently $\mathrm{f}_{\mathrm{ZB,N}}=$ $\mathrm{f}_{\mathrm{n}} 1000 / \mathrm{f}_{\mathrm{cv}}=67.6 \mathrm{mgN} / \mathrm{gCOD}$. The experimental basis for this were the approximately constant measured COD/VSS and TKN/VSS ratios (within the margins of experimental error) of the AS at different sludge ages despite the significant variation in the relative proportions of $\mathrm{OHO}$ biomass, endogenous residue and unbiodegradable particulate organics from the influent with sludge age. In the validation of the steady state AD model, Sötemann et al. (2005b) accepted that the unbiodegradable particulate organics have the same $\mathrm{CHON}$ composition as the biodegradable particulate organics and hence have equal COD/VSS and TKN/COD ratios. However, it appears that the COD/VSS and TKN/COD ratios of these two organic fractions differ significantly from each other and the values accepted for AS. Characterisation of the $\mathrm{PS}$ in AD allows better estimates to be made of the COD/VSS $\left(f_{c v}\right)$, TKN/VSS $\left(f_{n}\right)$ and C/VSS $\left(f_{c}\right)$ ratios of the biodegradable and unbiodegradable particulate organics (COD) from the influent wastewater.

In terms of the AD model structure, the COD/VSS, N/ COD and C/VSS ratios of the biodegradable particulate PS organics can be calculated from the VSS and particulate biodegradable COD removals, the FSA released and the C in the gas generated during anaerobic digestion. From the experimental data of Izzett et al. (1992), Moen et al. (2001) and Ristow et al. (2005), the average COD/VSS, N/COD and $\mathrm{C} / \mathrm{VSS}$ ratios of the biodegradable organics were calculated in this way. Then by deducting the COD, VSS and OrgN contribution of the biodegradable particulate organics from the measured influent particulate COD, VSS and $\operatorname{OrgN}$, the COD/VSS and N/COD ratios of the unbiodegradable particulate organics were calculated. The results are listed in Table 1. Also listed in Table 1 are the COD/VSS, N/COD and C/VSS ratios for the elemental composition of PS particulate organics measured by Sötemann et al. (2005b). From Table 1, it can be seen that the calculated N/COD ratio of the unbiodegradable particulate organics is nearly four times higher than that for biodegradable particulate organics and is significantly below the ratio accepted in ND AS models ( $f_{\mathrm{ZB}, \mathrm{N}}$ $=40 \mathrm{vs} 68 \mathrm{mgN} / \mathrm{gCOD}$ ). Also, the COD/VSS ratio of the unbiodegradable particulate organics is higher than that for biodegradable particulate organics, but the variation in the results is large. While these differences make relatively little difference to the AS system itself, they should to be taken into account in an AS model as part of a plant-wide WWTP model, because these differences can significantly affect the $\mathrm{COD}$ and $\mathrm{N}$ compound fluxes split between AS and sludge treatment, and hence the $\mathrm{pH}$ established in a PS anaerobic digester. The effect of applying different COD/VSS and N/COD ratios to the three solids components making up AS organics, and to the PS biodegradable and unbiodegradable particulate organics fed to the $\mathrm{AD}$, clearly needs further investigation. In the interim, for AS systems, the commonly accepted COD/VSS and N/COD ratios, i.e. $\mathrm{f}_{\mathrm{cv}}=1.48 \mathrm{mgCOD} /$ $\mathrm{mgVSS}$ and $\mathrm{f}_{\mathrm{ZB}, \mathrm{N}}=67.6 \mathrm{mgN} / \mathrm{gCOD}\left(\mathrm{f}_{\mathrm{n}}=0.10 \mathrm{mgN} / \mathrm{mgVSS}\right)$ will be used where required in this series of four papers.

\begin{tabular}{|c|c|c|c|c|c|c|c|c|}
\hline $\begin{array}{r}\text { COD/VSS, N/COD an } \\
\text { particulate orgar } \\
\text { anaerobic digester }\end{array}$ & $\begin{array}{l}\text { VSS r } \\
\text { calcul } \\
\text { luent a }\end{array}$ & $\begin{array}{l}\text { s of pri } \\
\text { d from } \\
\text { effluen } \\
\text { anc }\end{array}$ & $\begin{array}{l}\text { TABLE } \\
\text { hary sluc } \\
\text { he influe } \\
\text { COD (ex } \\
\text { gas pro }\end{array}$ & $\begin{array}{l}\text { e (PS) } \\
\text { PS rat } \\
\text { uding } \\
\text { ction }\end{array}$ & $\begin{array}{l}\text { iodegra } \\
\text { os and } t \\
\text { FA), VSS }\end{array}$ & $\begin{array}{l}\text { ole an } \\
\text { chang } \\
\text { id FS }\end{array}$ & $\begin{array}{l}\text { nbioc } \\
\text { betw } \\
\text { oncer }\end{array}$ & $\begin{array}{l}\text { adable } \\
\text { PS } \\
\text { tions }\end{array}$ \\
\hline Data source & & COD/V & SS (gCOD & VSS) & TKN/C & $\mathrm{OD}(\mathrm{mgN}$ & COD) & C/VSS ${ }^{a}$ \\
\hline & $\begin{array}{c}\text { COD } \\
\text { fraction }\end{array}$ & Meas'd ${ }^{b}$ & Biodeg & Unbio & Meas'd ${ }^{b}$ & Biodeg & Unbio & Biodeg \\
\hline Izzett et al. (1992) & 0.36 & 1.583 & 1.627 & 1.503 & 22.1 & 12.2 & 39.7 & $0.608^{\mathrm{c}}$ \\
\hline Moen et al. (2001) & 0.35 & 1.617 & 1.321 & 2.167 & - & - & - & 0.502 \\
\hline Ristow et al. (2005) & 0.334 & 1.931 & 1.307 & 3.176 & 20.4 & 10.1 & 40.9 & $0.550^{\mathrm{d}}$ \\
\hline Sötemann et al. $(2005 b)^{\mathrm{e}}$ & - & - & 1.568 & - & - & 20.9 & - & 0.502 \\
\hline Simulation example ${ }^{\mathrm{f}}$ & 0.314 & 1.641 & 1.715 & 1.48 & 30.4 & 13.4 & 67.6 & 0.502 \\
\hline
\end{tabular}

${ }^{a} \mathrm{gC} / \mathrm{gVSS}$

${ }^{\mathrm{b}}$ Calculated from measured values on influent - i.e. mixed biodegradable and unbiodegradable organics

${ }^{c}$ High due to $108 \%$ COD balance on experimental AD (Standard deviation \pm 0.018 )

d Average of 13 ADs with COD balances between 97 to $103 \%$ (Standard deviation \pm 0.085 )

${ }^{e}$ For $\mathrm{C}_{35} \mathrm{H}_{7} \mathrm{O}_{2} \mathrm{~N}_{0196}$ determined by Sötemann et al. (2005b) for PS biodegradable organics

${ }^{\mathrm{f}}$ Used in ASM1 simulation in Sötemann et al. (2006, Part 4) 


\section{Removal of biodegradable and unbiodegradable organics in PSTs}

Equation (1) also shows that the \% removal of unbiodegradable particulate organics (COD) in PSTs is much higher $(83 \%$ for the selected $\mathrm{f}_{\mathrm{S}^{\prime} \text { up }}$ values above) than that of biodegradable particulate organics $(38 \%)$. This has been of serendipitous economic benefit for the AS system treating settled wastewater and is the main reason why the biological reactor treating settled wastewater is so much smaller per kgCOD load compared with one treating raw wastewater: A large proportion of the unbiodegradable particulate organics from the influent is settleable and does not accumulate in the AS reactor, but rather in the PS. If lower \% removals of unbiodegradable particulate organics (COD) took place in PSTs (say 50\%), then settled wastewater AS reactors would have to be much larger for the same $\mathrm{kgCOD}$ applied and sludge age to accommodate the accumulation of this additional unbiodegradable particulate organics.

\section{Conclusions}

From this investigation of the continuity of wastewater organic (COD) and $\mathrm{N}$ compounds across the link between the primary settling tank (PST) and anaerobic digestion (AD) unit operations, the following conclusions can be made:

- Application of the COD, C and N mass balances steady state anaerobic digestion (AD) model of Sötemann et al. (2005b) to literature data of AD of primary sludge (PS) showed that this model satisfactorily predicted AD performance (gas production and composition, effluent COD, free and saline ammonia and alkalinity concentrations) and provided a mass balance based structure to determine the unbiodegradable organic $(C O D)$ fraction of $P S\left(f_{P^{\prime} \text { up }}\right)$. This fraction determined from the AD model matches very closely that calculated for PS from a mass balance around the PST for typical raw and settled wastewater characteristics.

- It follows from above that the PS characteristics can be calculated from mass balances around the PST so that the organic (COD) and $\mathrm{N}$ (and $\mathrm{C}$ if measured) concentrations and components, viz. biodegradable and unbiodegradable soluble and particulate, conform to continuity principles, and the influent unbiodegradable particulate organics determined from response of the AS system are also unbiodegradable under anaerobic digestion conditions.

- Anaerobic digestion of PS provides a basis to determine the COD/VSS, N/COD and C/VSS ratios of the influent wastewater biodegradable and unbiodegradable particulate organics. From data from several anaerobic digester studies, it was found that the COD/VSS $\left(\mathrm{f}_{\mathrm{cv}}\right)$ and N/COD $\left(\mathrm{f}_{\mathrm{ZB,N}}\right)$ ratios of influent unbiodegradable particulate organics $\left(\mathrm{S}_{\text {upi }}\right)$ are significantly higher than the ratios for biodegradable particulate organics $\left(\mathrm{S}_{\mathrm{bpi}}\right)$. For example - the N/COD ratio of unbiodegradable particulate organics was found to be four times higher ( $40 \mathrm{mgN} / \mathrm{gCOD})$ than for biodegradable particulate organics $(\sim 10 \mathrm{mgN} / \mathrm{gCOD})$. Also, the COD/ VSS and N/COD ratios for unbiodegradable organics are significantly different to the ratios commonly assumed for these organics in AS models, viz. $\mathrm{f}_{\mathrm{cv}}=1.48 \mathrm{mgCOD} / \mathrm{mgVSS}$ and $\mathrm{f}_{\mathrm{ZB}, \mathrm{N}}=67.6 \mathrm{mgN} / \mathrm{gCOD}\left(\mathrm{f}_{\mathrm{n}}=0.10 \mathrm{mgN} / \mathrm{mgVSS}\right)$. While these differences in the ratios make little difference to the AS system as a stand-alone operation, the differences are significant when tracking COD, VSS and N fluxes through a network of unit operations of a WWTP. Different N/COD ratios for the biodegradable and unbiodegradable particulate organics have been incorporated in ASM2 (Henze et al., 1995) but the experimental basis for the given values (40 and $30 \mathrm{mgN} / \mathrm{gCOD}$ respectively) is not given. This aspect requires further exploration in the context of plant-wide WWTP models.

- An aspect only peripherally considered in this paper is the C balance over the WWTP. While the C balance is not important for the AS system itself, the C content of PS and waste activated sludge is important for anaerobic digestion. From one data set on anaerobic digestion of PS, the calculated CHON composition of the particulate biodegradable organics of the PS from the VSS and biodegradable $\mathrm{COD}$ removed and free and saline ammonia generated (i.e. $\mathrm{C}_{3.5} \mathrm{H}_{7} \mathrm{O}_{2} \mathrm{~N}_{0.196}$ ) correlated closely with elemental analysis of PS from two full-scale WWTPs (Sötemann et al., 2005b). The CHON stoichiometry of AD of wastewater organics can be modified and applied to AS to include this system in the $\mathrm{C}$ balance over the WWTP. This, and the feasibility of developing approximate $\mathrm{CHON}$ stoichiometric formulae for the different influent wastewater organic fractions will be explored in further research to try to complete the $\mathrm{C}$ balance over the WWTP.

From the above, because in the steady state AD model of Sötemann et al. (2005b), the feed PS characteristics are specified in terms of commonly measured parameters like COD, VSS, TKN, FSA, TP and TSS, see Ekama et al., 2006a, Part 2) and the unbiodegradable particulate COD fraction of the PS ( $\left.f_{P^{\prime} \text { up }}\right)$ (and VSS/TSS ratio) can be calculated from the raw and settled wastewater characteristics selected for the PST, this AD model can be readily integrated into a steady state mass balance model for the entire WWTP. This establishes the link between the PST and AD of PS, by ensuring common and readily measurable compounds at the interconnection between these two unit operations.

\section{Acknowledgments}

This research was supported by the Water Research Commission, the National Research Foundation and the University of Cape Town and is published with their permission.

\section{References}

BATSTONE DJ, KELLER J, ANGELIDAKI I, KALYUZHNYI SV, PAVLOSTATHIS SG, ROZZI A, SANDERS WTM, SIEGRIST H and VAVILIN VA (2002) Anaerobic Digestion Model No 1 (ADM1), Scientific and Technical Report No 9, International Water Association (IWA), London, UK.

COPP JB, JEPPSSON U and ROSEN C (2003) Towards an ASM1ADM1 state variable interface for plant-wide wastewater treatment modelling. Procs. $76^{\text {th }}$ Annual Water Environment Federation Conference and Exhibition. Oct 11-15, Los Angeles, USA.

COPP JB, PEERBOLTE A, SNOWLING S, SCHRAA O, FROELICH $D$ and BELIA E (2004) Integrating anaerobic digestion into plantwide wastewater treatment modelling - Experience with data from a large wastewater treatment plant. In: Guiot S and Pavlostathis SG (eds.) Procs AD2004 - $10^{\text {th }}$ World Congress on Anaerobic Digestion. 1362-1365.

DOLD PL, EKAMA GA and MARAIS GvR (1980) A general model for the activate sludge process. Prog. Water Technol. 12 (Tor) 47-77.

DOLD PL, WENTZEL MC, BILLING AE, EKAMA GA and MARAIS GvR (1991) Activated Sludge Simulation Programs. WRC Report No TT 52/91, Water Research Commission, Private Bag X03, Gezina, 0031, South Africa. 
ECKENFELDER WW (Jr) (1980) Principles of Water Quality Management. CBI Publishing Company Inc., Boston, Massachusetts, USA.

EKAMA GA, WENTZEL MC and SÖTEMANN SW (2006a) Mass balance-based plant-wide wastewater treatment plant models - Part 2: Tracking the influent inorganic suspended solids. Water SA 32 (3) $277-286$.

EKAMA GA, SÖTEMANN SW and WENTZEL MC (2006b) Mass balance-based plant-wide wastewater treatment plant models - Part 3: Biodegradability of activated sludge organics under anaerobic conditions. Water SA 32 (3) 287-296.

HENZE M, GRADY CPL (Jr), GUJER W, MARAIS GvR and MATSUO T (1987) Activated Sludge Model No 1, IWA Scientific and Technical Report No 1, IWA London. ISSN 1010-707X. 33 pp.

HENZE M, GUJER W, MINO T, MATSUO T, WENTZEL MC and MARAIS GvR (1995) Activated sludge model No 2. IWA Scientific and Technical Report No 3, IWA London. ISBN 1-900222-00-0, 32 pp.

HUETE E, DE GRACIA M, AYESA E and GARCIA-HERAS JL (2005) ADM1-based methodology for the characterization of influent sludge in anaerobic digestion. Proc. $1^{\text {st }}$ Int. Workshop on the IWA Anaerobic Digestion Model No. 1 (ADM1), Sept 2-4, Lyngby, Denmark. 185-192.

IZZETT HB, WENTZEL MC and EKAMA GA (1992) The Effect of Thermophilic Heat Treatment on the Anaerobic Digestibility of Primary Sludge. Research Report W76, Univ. of Cape Town, Dept. of Civil Eng. Rondebosch 7701, Cape, South Africa.

JANUS HM and VAN DER ROEST HF (1997) Don't reject the idea of treating reject water. Water Sci. Technol. 35 (10) 27-34.

MAURER M and GUJER W (1994) Prediction of the performance of enhanced biological phosphorus removal plants. Water Sci. Technol. 30 (6) 333-344.

MOEN G, STENSEL HD, LEPISTO R and FERGUSON J (2001) Effect of retention time on the performance of thermophilic and mesophilic digestion. Proc. $74^{\text {th }}$ Annual Water Environ. Fed. Conf. and Exhib. Atlanta, USA
PITMAN AR, DEACON SL and ALEXANDER WV (1991) The thickening and treatment of sewage sludge to minimize phosphorus release. Water Res. 25 (10) 1285-1294.

O'ROURKE JT (1968) Kinetics of Anaerobic Treatment at Reduced Temperatures. Ph.D. Dissertation, Department of Civil Engineering, Stanford University.

RISTOW NE, SÖTEMANN SW, LOEWENTHAL RE, WENTZEL MC and EKAMA GA (2005) Hydrolysis of Primary Sludge under Methanogenic, Acidogenic and Sulfate Reducing Conditions. WRC Report No. 1216/1/05, Water Research Commission, Private Bag X03, Gezina, 0031, RSA. ISBN 1-77005-290-5.

SÖTEMANN SW, MUSVOTO EV, WENTZEL MC and EKAMA GA (2005a) Integrated chemical, physical and biological processes modelling Part 1 - Anoxic-aerobic $\mathrm{C}$ and $\mathrm{N}$ removal in the activated sludge system. Water SA 31 (4) 529-544.

SÖTEMANN SW, RISTOW NE, WENTZEL MC and EKAMA GA (2005b) A steady state model for anaerobic digestion of sewage sludges. Water SA 31 (4) 511-527.

SÖTEMANN SW, WENTZEL MC and EKAMA GA (2006) Mass balance-based plant-wide wastewater treatment plant models - Part 4 Aerobic digestion of primary and waste activated sludges. Water $S A$ 32 (3) 297-306

WILD D and SIEGRIST H (1999) The simulation of nutrient fluxes in wastewater treatment plants with EBPR. Water Res. 33 (7) 16521662

WENTZEL MC, EKAMA GA, DOLD PL and MARAIS GvR (1990) Biological excess phosphorus removal - Steady state process design. Water SA 16 (1) 29-48.

WENTZEL MC, EKAMA GA and MARAIS GvR (1992) Processes and modelling of nitrification denitrification biological excess phosphorus removal systems - a review. Water Sci. Technol. 25 (6) 59-82.

WRC (1984) Theory, Design and Operation of Nutrient Remova Activated Sludge Processes. Wiechers HNS (ed.), Water Research Commission, Private Bag X03, Gezina, 0031, RSA. ISBN 0908356137. 